\title{
Against Her Kind: The Phenomenom of Women Against Women in Ovia Cult Worship
}

\author{
Anthonia Makwemoisa Yakubu \\ School of Arts \& Social Sciences \\ National Open University of Nigeria \\ Lagos, Nigeria \\ E-mail: ayakubu@noun.edu.ng; brigettemak@gmail.com
}

Doi:10.7575/aiac.alls.v.5n.5p.133

URL: http://dx.doi.org/10.7575/aiac.alls.v.5n.5p.133
Received: 11/07/2014

Accepted: 02/08/2014

\begin{abstract}
This paper addresses the incidence of 'Women against Women' in Nigerian folklore. Much has been written on Nigerian folklore, but mainly from within the mortal axis, as reflected in many folktales that cut across different communities in Nigeria. However, it has been observed that this gender phenomenon extends to the supernatural realm, where gods and goddesses, especially the latter, seem to prefer members of the opposite sex as the objects of their attention and goodwill. This paper focuses on Benin mythology, with particular emphasis on the cult and festivals of the Bini goddess, Ovia. Of the origin stories of most of the gods and goddesses in Bini mythology, the Ovia cult is unique, as it provides a gender reason why membership is restricted to men. Adopting a psychoanalytical and feminist approach, the paper concludes that Ovia's deliberate exclusion of women re-echoes the negativity ascribed to women.
\end{abstract}

Keywords: women, folklore, patriarchy, gender

\section{Introduction}

A common thinking exists, especially among people who live in patriarchal societies, that women, in relation to men, are physically and mentally weak, vain, distrustful, lazy, and calculative. It is also believed that women are naturally competitive, hence their seeming difficult and fractious relationship with one another. Their competitive spirit is usually deployed to pull down other women, especially those whom they perceive as threats to their own position or success. This explains why the common saying, "women are their own worst enemies," is considered a universal truth by many.

Using biological reasons to support their stance, exponents of patriarchy agree that the female homo sapiens has a "weak" brain that cannot stretch its capacities beyond certain immediate and often emotive limits (Gray, 1981; Benbow and Benbow, 1984; Birke, 1986; Broverman et al, 1998). Women and men live in a patriarchal environment, which thrives on the belief that women are unequal to men biologically and psychologically. The perceived inequality is then translated, through the practice of folklore, to mean that the female sex is subservient to the male. This biased view of the subservient nature of women to men is also maintained through social conditioning. One of the most important aspects of the social conditioning is that women do not like and cannot trust one another. This belief is embedded in folktales, myths, and proverbs. Psychoanalytically, it is unconsciously communicated in women's relationship with other women who are not their equal on the social ladder; or who are real or potential threats/competitors for the small space they enjoy in the patriarchal order.

However, the mistrust among women is not observed in their relationship with men and with deities in the spiritual realm. In the former, women are conditioned to owe their allegiance to men, and so they act to protect the viability of the unequitable relationship, while in the latter, the supremacy of the gods and goddesses and the power relations involved, presupposes a benefactor/beneficiary relationship, which finds expression in folklore, especially in festivals. The paper provides an alternative and critical way of evaluating gender relations, not only between members of the opposite sex, but also among members of the same sex. Importantly, it shows the central place folklore, especially through cult worship/festivals, occupies in shaping and consolidating various elements of gender relations.

\subsection{Between Psychoanalysis and Feminism}

Psychoanalysis affirms that all human actions have 'hidden' or subconscious meanings, which can be used as springboards for understanding human experience and the reasons behind certain actions. Contemporary human life is submerged in multiple, complex and fragmented experiences. Within the reality of psychoanalysis, the disconnected pieces of experience of the modern world can be explained under the Freudian concept of over-determination - what we see or experience has multiple causes or origins, which can be ascertained by the conscious examination of the unconscious. Women relate with each other mainly within the categories of race, ethnicity, class, and religion. Adopting a psychoanalytic framework will help to reveal the complex strands which permeate these factors in relation to gender. 
Psychoanalysis has been increasingly employed as a framework in the discourse of culture, language, art, female sexuality, etc. Interestingly, it is being used hand in hand with feminism, and as a result of 'the marriage', the term 'Psychoanalytic Feminism' has come to mean the multi-faceted complexities of a broad ideology.

However, psychoanalysis does not adequately explain the phenomenon of 'women against women'. Its analysis of gender relations is significantly sexist and flawed - an underlying thought that runs through it is the inferior status of women (Harding, 1986; 1993; Wertheim, 1995). Its postulations on femininity are, especially from the biological angle, unrealistic and sometimes laughable (Gallup, 1982; Fuss, 1995). The adoption of the feminist theory, therefore, makes up for the inability of the psychoanalytic theory to logically present women's socio-biological experience in a scientifically convincing manner (Barrett, 1990).

Feminism is a broad-based philosophical notion or theory that relates to women's socio-historical conditions. Its theory, diverse in thought and methodology, revolves around the 'woman question'. It specifically addresses the oppression of the female, in relation to the male, in a patriarchal and often capitalist society. A critical aspect of feminist criticism of patriarchy is the subjectivity of women. Subjectivity is closely intertwined with ideology and sexuality. These three but one experiences capture in sum the social relations of the female sex to the male sex, irrespective of the different polarities that make each woman's experience unique. Female subjectivity encapsulates the physical, mental, spiritual, and communal lives of the female sex.

Male and female are subjects, but each person's subjectivity hinges on different interpretations, ideologies and experiences. Men and women experience imposed subjectivities, but of different types, and in varying degrees. The subjectivity of men is mainly positive and empowering in relation to that of women. It is this gender experience that Simone de Beauvoir (1949) describes as the 'Other' experience. She postulates that women's personhood and subjectivity is assessed in relation to men's. Man can stand on his own; he is independent, needing no appendages to remain relevant and significant to himself and his community. But the woman can only experience a measure of importance and dignity from the person of the man in her life. In this way, society views her as the 'other', different in a negative sort of way, needing a male 'passport' to acquire some form of relevance in the society.

Literature and literary texts have not only been major avenues in the interplay of difference and subjectivity; they have also produced 'the fused language of class, race and gender' (Davis and Schleifer, 1998). Belsey (1985) argues that fiction, or the text, or folklore, plays a major role in the construction of subjectivity, especially that of women. Through the text, subjectivities of particular sexes, and their responses are transmitted subtly, and sometimes unconsciously, to the reader.

However, some African female scholars have called for caution in the interpretation of the complex interrelatedness of gender, patriarchy, men, and women. For instance, in Nigeria, the belief exists in some quarters that the relationship between the sexes is that of complementarity, and not one of master and subordinate, or of superiority and inferiority (Ogundipe-Leslie, 1985; Amadiume, 1987, 1998; 2000; Kolawole, 1997; Nnaemeka, 1995, 1998; Oluwole, 1993; Oyewumni, 1997; 2004; 2005; Nzegwu, 2006).

But there is a growing body of work that negates the above thesis. The argument is that only very few women, especially those who enjoyed filial association with royalty, had any important say in the socio-political management of a community. Examples of such women are queen mothers, princesses, and goddesses (Bay, 1998).

\subsubsection{The Place of Women in Mythology}

Many myths revolve around women, even in contemporary times. Over the centuries, some perceptions about women have just refused to be wiped out, in spite of the gallant strides many women, in Africa for example, have made since pre-colonial times (Chukwukere, 1995; Ogundipe-Leslie, 2007). Many of such perceptions came into being through myths. New myths are churned out to buttress the existing ones. These retain their gripping effect on our consciousness, especially on the male consciousness because, where they concern women, they are mostly negative in nature (Ezeigbo, 1993:93).

Myths provide the basis of legality for women's conditions and sustain the status quo by consolidating the power relations between the male and the female. They constitute a common reference in justifying women's inferior status in society. They are also used, subtly or otherwise, to cajole women into accepting their inferior status as "God-given," "natural", and "normal".

The anonymity of the sources of myths and the communal nature of their ownership make their internalisation faster and effective as they are often cloaked in the garb of divinity. Thus, they are powerful tools for transmitting and enforcing moral codes and discipline, and for defining and sustaining gender relations. They confer on every member of the community a sense of identity and social acceptability. They form the bedrock of general socio-cultural beliefs. They are also employed in explaining and in legitimising oppression. As a result of the internalisation of these myths over a long period, women come to see their inferior status in the social, political and economic realms as "natural" and somewhat irreversible. Gendered myths have thus contributed largely to violence against women, women's inheritance problems, women's poverty, and several dangerous socio-cultural practices women are made to participate in - aspects of puberty/fertility rites, circumcision, widowhood rites, etc.

Ironically, women not only internalise the negative values attributed to them in myths, but also help in perpetuating these against their fellow women. This attitude, according to Ogundipe Leslie (1985:127), is due to the "psychology of 
servitude" which many women exhibit. It is the constant desire and anxiety to please the "master". The attitude is made worse by women's tendency to always blame themselves for whatever oppression they are made to undergo.

\subsubsection{Women in Benin Folklore}

The Benin make up the major tribe in Edo State, Nigeria. They and the other tribes in the state are referred to as Edo. Their different dialects are lumped together under one generic term: Edo. Traditionally, and up to the present, the Edo people regard Benin City as their spiritual home. Strong cultural and historical ties connect the people to Benin City. The Benin kingdom is a conglomeration of many towns founded at different periods of its history. Some of these towns are Eko Ohae, Usama, Uselu, Udin Ama-Mieson Aimiuwa, Use, Isekhere, Urho Okpata, Eguae Oba, and Ekiokpagha.

In its earliest times, Benin was ruled by paramount rulers known as the Ogisos. The dynasty started about the tenth century and, by the fourteenth century, was firmly established (Bradbury, 1957; 1973). The Ogisos ruled the kingdom for many centuries and expanded its territorial base by bringing small independent states under its control. Thirty one Ogisos reigned, and some of them were women (Ryder, 1977). The first Ogiso was Obagodo, and the last was Owodo, who was exiled from the kingdom for commanding the execution of a pregnant woman.

The indigenous people of Benin are usually addressed as Bini. They call their city 'Ore Edo', the city of Edo, and they addressed themselves as Edo. Ore-Edo, or Benin City, formerly known as Igodomigodo, shares some certain similarities in language, ideas, and practices (Bradbury, 1973; Nevadomsky, 1993) with the Yoruba and Igbo of the western and eastern parts of Nigeria respectively. This is perhaps because Benin occupies the forest belt region that was between the Yoruba Empire of Oyo and some Igbo states like Ubulu-Ukwu and Agbor. (Benin's middle position led to the creation of a Midwest Region from the Yoruba western region in 1963). For instance, all three practised traditional religion divination system known as Ifa in Yoruba, Afa in Igbo, and Iha in Edo.

The three major ethnic groups in Nigeria - the Yoruba, Igbo and Hausa - share a similar personal destiny belief system with the Binis. To the Yoruba, one's destiny is located in, and personified by the head, Ori. The head is also the guardian spirit of the individual. For the Igbo, one's destiny is located within the self but guided with the assistance of one's chi, the person's guardian spirit. For the Bini, one's destiny in life is guarded by, and inhabits two members of the body: the hand (ikega) and the head (uhumwu). Ikega denotes enterprise and resourcefulness, and in the olden days, Benin farmers and warriors offer sacrifices to the cult of the hand, ikegodo, for wealth, success, and social achievements (Bradbury, 1973:264). On one's head rests the capacity and ability for survival, posperity, and excellence. The head guides and directs one through the turbulent waves of life. It is also "the seat of thinking" (iroro), judgment (enwae) and will or character (exoe). Offerings to one's head are usually carried out by a husband and father, the head of the house, for himself, his wives and children. Similarly, the Oba of Benin is the head of the kingdom. He offers sacrifices to the cult of the head for himself, his wives and children, his chiefs, and his subjects. Similar to the Igbo guardian spirit, the $c h i$, is the Ehi, one's destiny and guide in the spirit world. The Bini believe that before each person's birth, one chooses for him/herself the life s/he wants to live on earth, and Ehi stands by to place a stamp of confirmation on one's path. $\mathrm{S} /$ he is constantly invoked when one experiences failure and stunted growth in life.

\subsubsection{The Place of Women in Benin Society}

Women hardly feature in the political history of Benin. Women do not feature as political office holders in the cabinet of the Oba. In the Queen mother's (Iye Oba) palace at Uselu, a number of women serve as her chiefs but this is mainly at an advisory level. A highly traditional and patriarchal state, which gives due honour to the queen mothers, majority of the women pale into insignificance in relation to the rich history and culture of the region. Even though there are references in Benin history of river goddesses and ancient shrines of priestesses, there seems to be a conscious attempt on the part of many Bini not to dwell on this (Ogbomo, 1997). Also, among the early Ogisos that ruled Benin were women. There was Ogiso Emose who brought prosperity and peace to the kingdom (Ikpe, 1997; 1999).

Majority of the women were wives and mothers who worked alongside the men folk for the success of the empire. Many of them were involved in agricultural labour - they assisted their husbands, masters and parents on their farms and plantations. The major cash crop was yam and was cultivated only by men. Women were in charge of subsidiary crops like corn, groundnuts, pepper, melon and beans. By a stroke of luck coupled with hard work, one of these "faceless" women eventually became the richest woman in Benin. She was an employer of many labourers and slaves on her farms and in her businesses. However, Oba Ewuare could not stand the challenge from a woman and had her murdered (Egharevba, 1947; 1952; 1960). The same Oba Ewuare honoured Emotan, a trader who offered him financial and spiritual support in his bid for the ascension to the throne. He also instituted the Ugie Ewere festival to mark his happy, prosperous and peaceful marriage to his favourite wife, Ewere.

Over the centuries, few Benin women rise from the blanket of mediocrity apportioned to them to shine like lone stars. For instance, in the seventeenth century, a certain woman, Arabe, who owned and managed a large chain of businesses, was deified by the ruling monarch. She was humble, resourceful and a good cook who sometimes provided free food during festivals. She was said to have created the cotton seed/palm fruit soup, and to have popularised the bitter leaf soup in Benin, an art she learnt from her trade dealings with the Igbo (Ikpe, 1997). Another group of women that fall into the "lone star" category were the queen mothers. The institution existed between 1509-1536. It was started by Oba Esigie who created the title of Iye Oba in honour of his mother, Queen Idia, with her palace in Uselu. He had every reason to be grateful to his mother. It was the timely action of his mother that sealed his fate as the next Oba of Benin. His mother gave birth to him a few hours after the birth of another prince, Arhuanrhuan, by one of her co-wives. In 
those days, the Oba's pregnant wives were usually taken out of the palace to villages outside the capital where they are tendered with care until they were delivered of their children (Ryder, 1977).

When a child is born, the mother must notify the palace immediately. This was how the birth dates were recorded. For unknown reasons, Queen Idia's co-wife did not relay the news of her child's birth to the palace on time. Queen Idia seized the delay to quickly relay her child, Esigie's birth. This was how Esigie became the heir to his father's throne. However, Prince Arhuanrhuan and his mother started series of succession disputes, which culminated into a full-blown war. Oba Esigie, with the help of his mother, defeated Arhuanrhuan and his troops. The militant streak in Queen Idia was also put to good use in $1515 \mathrm{AD}$ during the war between Benin and Idah. She led the Benin troops to victory. Throughout her lifetime, she protected the kingship of her son and offered him consistent moral and spiritual support (Salami-Agunliye, 2008). To commemorate her lifetime and achievement for posterity, the guild of wood carvers, the Owinna, was asked to carve an ivory mask of her face which was achieved in 1520 AD. This mask was the official emblem of the Second World Black and African Festival of Arts and Culture (FESTAC), which held in Lagos in 1977. But the institution of the queen mother did not advance the progress of the generality of Bini women. The queen mother's main interest was always in consolidating her son's power and position.

The deification of mothers, symbolised by the tradition of the queen mother, was not reserved for royalty alone. Many Benin citizens have ancestral shrines mounted in their homes where they commune with the spirits of their dead parents for spiritual and material assistance. It is often the eldest male, on behalf of his siblings, who erects this shrine within the confines of his home in honour of his late parent(s). The objects commonly found in the shrine are a bell (to summon the spirit(s) of the dead parent(s) from the spirits world) and an ukhurhe, a "carved wooden rattle staff of paternal authority" (Nevadomsky 1993: 30). This staff is usually used by the head of the house to ratify any important decision taken. Close to the room that houses the ancestral shrine is another room that contains a shrine honouring deceased mothers. An important object of the shrine is a carved wooden hen, symbolising maternal love, duty, and protection from the hen (mother) to her chicks (children).

Yet, women in the dominant Benin history and tradition were more or less commodified objects. The larger than life image of the Oba, maintained by an assortment of myths and factual events, demands that he has a large retinue of wives, concubines and children. Many of the Obas wives and concubines reluctantly joins his harem (erie) because of the fear of royal reprisals. The Ibiwe guild or associations is in charge of the maintenance and discipline of the large harem of women and their children. The harem has between seven hundred and one thousand wives and concubines, with their servants and slaves. The Ibiwe and Iye-oba teach the iloi, the many wives of the Oba, songs, folktales and dance to prevent boredom. During the reign of Aiguobasimwin, Eweka II, from 1914-1933, some of his chiefs made an accusation to the British Resident officer that he, Eweka II, married many of his wives against their will, and that a good number of his concubines are forcibly kept in the harem (Bradbury, 103-104). The accusation was, of course, genuine in the context of the deprivation of the women's social rights. They were expected to be submissive to the authority of men, and to remain silent in the face of their own objections. There is also the view that the large number of women in the Oba's harem served to provide "interesting" distractions to an otherwise semi-secluded king who, traditionally, is not allowed to step out of his palace more than twice in a year. Some of the Oba's chiefs capitalised on the physical absence of the Oba in state affairs to amass untold wealth to themselves without his knowledge. An instance is mentioned of Oba Ahenzae in $1651 \mathrm{AD}$ who was provided with over five hundred concubines by Uwangue, the head of the Iwebo, the most senior palace society, in order for him (the latter) to pursue his selfish interests (Ryder, 17-18).

However, there is also the view that the Oba does not have carnal knowledge of all his women. A large number of these women he gives out as gifts or reward to his chiefs and important visitors for services rendered (Bradbury: 103). This opinion is fundamentally not different from the initial one. The bottom line is that women are seen as commodities to satisfy the cravings and desires of men, their masters. When these masters wear the garb of royalty, it becomes more difficult for ordinary women to register their displeasure. The authority bestowed on men could be exercised in favour of women. Contrary to tradition, Okoro Edokporhogbunyunmwun, Oba Akenzua II, who ascended the throne when his father, Eweka II died in 1933, an alumni of King's College, Lagos, dissolved his late father's harem and asked many of the girls engaged to his father to go, instead of being compelled to marry him. Much relieved, they went back into the larger society to face other challenges. Importantly (as is illustrated below), the place of women in Benin history and culture has been accentuated by various aspects of the people's folklore which is largely interwoven with the various bits of daily experience.

\subsubsection{Bini (God)dessess: Between Obiemwen and Olokun}

The major origin myth of the Benin is peopled by only men. Benin was believed to have been founded by Osanobua's (the Supreme Being) youngest son. Osanobua had sent all his children from heaven to go and live on earth. Each of the brothers, among whom were the founding monarchs of Ile Ife (Uhe) and other Yoruba states, left for the earth with magical skills, wealth, food, and other items that they might need on the long journey. However, the youngest son, following the advice of a 'bird friend', took along with him the shell of a snail. When the brothers arrived the earth, they found the earth completely submerged in water. There was no land to place their feet on. The bird friend of the youngest son commanded him to turn over the snail shell with him. He did, and sand dropped from the shell and covered the waters of the earth to form land. He then became the owner of the land and his older brothers, in exchange for their possessions, leased some part of the land to stay on. The youngest sibling became the richest and the most powerful being on earth and was thus made the first Oba of Benin (Ben-Amos, 1980; Peavy, 2009). 
Like the Yoruba, Benin people believe that they are the originators of life and civilisation. The story of their origin is encapsulated in the folkloric genres of songs, festivals, folktales, proverbs, and ritual performances. Their centrality to creation is enclosed in the literature 'Edo-ore - I-se-agbon!'- ('Edo, the land that extended to the visible world!'). In an origin myth that features a woman playing a primary role in it, the Bini trace their origins to primordial times. Osanobua, while at his creative task, decided to fill the world he had earlier created with people and other living things. The world he had created was a vast expanse of water, broken only by a lone ikhinmwin tree on which there lived owonwon, the long - beaked hornbill bird. Osanobua sent three of his children into the watery world to carry out the project. These children were Obiemwen (the oldest, and a daughter), Olokun, and Ogiuwu. On their way down to the earth, Owonwon shouted up to them that they should come with a snail shell. When they got to the centre of the watery world, Obiemwen turned over the shell. And sand poured out from it on to the waters and became land. The chameleon tested with its feet the firmness of the land, and assured all that the land was fit and firm enough for dwelling. Osanobua then shared out the land and responsibilities: Obiemwen was placed in charge of childbirth and agriculture; Olokun was given the power, initiative and discretion, to bestow wealth; while Ogiuwu became the bearer and giver of death (Nevadonsky, 1993). This particular origin myth iterates the maternal essence of women and places a seal on their existence as biological and economic catalysts, with irredeemable cosmic, social, and metaphysical categories of dependence.

Many of Benin creation myths do not feature women, in spite of the latter's presence in the history of the empire. Obiemwen, Osanobua's daughter used to be actively revered in the old Benin empire, and the Oba used to appoint a priest to manage her shrine (Ben- Amos, 1980). In modern times, many do not know her as the creator's child. Rather, they refer to her as the senior wife of whatever major deity a particular community worships. Her reproductive roles are captured in praise terms: "the mother of all human beings and all living things... the source and goddess of breeding" (Egharevba 1946: 84). She is addressed as Uhe- ne- iro 'the vuva opening of the wide road' (Nevadomsky, 1993, 23). She is also defined as the goddess of food and fertility. However, generally, the knowledge and worship of her have decreased tremendously over the centuries.

A major reason for this was the increasing profile and the worship of another god, Olokun, the owner of the ocean. The significance of water in Benin cosmology is another reason for the massive adherence to the worship of Olokun. The Bini believe that the world is encircled by water, which all souls must pass across on their journey either to the land of the spirits (enrinmwin) or to the land of the living (agbon). Politically, the increased worship of Olokun reflected the new interest in coastal trade by the Benin monarchy. With the coming of the Portuguese in 1485, during the reign of Oba Ozolua, the tempo of coastal trade increased. Benin expanded its territory to include small coastal states. The newfound prosperity enjoyed by the monarchy, and indirectly, the whole of Benin, was adduced to the deity Olokun, who had brought wealth from the sea to the people.

Olokun is usually represented by a large box wrapped in white cloth on which many mirrors are hung. This box, Okun, is used in funeral rites to symbolically carry the deceased's wealth, valuables, and status across the river to the land of the spirits. Many Bini worship this deity who is believed to bless his adherents with prosperity, happiness, and fertility. Many homes have shrines dedicated to Olokun, decorated with clay water pots (uru) small brass ladders, and miniature canoes with paddles to symbolise social mobility, white chalk or kaolin (orhne) for purity and happiness, and cowries for prosperity. Ironically, even though the deity is male, it is girls and women who make up the highest number of his adherents. This is because the major role ascribed to the deity is reproductive - women who want to conceive, those who want more children, and those who are yet to conceive troop to his shrine with fervent supplications. Like many patriarchal societies, the Bini expect a married woman to bear children, especially sons. It is believed that Olokun does not only bestows children; he also blesses his followers with prosperity. He is known and addressed by feminine names, which are actually some of the names of his wives and concubines: Imene, his favourite wife; Akpowa, his faithful servant; and Igbaghon, his beautiful concubine.

Closely worshipped with Olokun is the Mamiwata, who Egharevba (1947: 84) refers to as one of Olokun's wife. The two deities bestow similar favours on their adherents: wealth, prosperity, and children. However, there are some marked differences: Olokun is male, while Mamiwata is female. For the object of worship, kaolin chalk is used for the former, while perfumed white powder is used for the latter. The musical instruments used in the worship of the deities are also different - Olokun's adherents dance to the beats of the ukuse, a beaded calabash, while Mamiwata's worshippers dance to music from the guitar. The praise chant, "Oba-ne-ane" ("Gods of the sea") is sung to the two deities and to other deity of the sea.

The abandonment of the mythic essence of Obiemwen for the materialistic essence of Olokun, which by extension now incorporates even the reproductive role of Obiemwen, reflects the two ideological leanings of the average Bini - wealth and children. It also reflects the materialistic nature of the Bini people and their redefinition of mythic and gender essences based on materialist thought and practice.

\subsubsection{Women against Women: Ovia Cult Rites}

One of the most popular Benin mythological figures is a young woman called Ovia, who was said to have lived during the reign of Oba Ewuare. Today, apart from Olokun and Mamiwata, she is widely worshipped and has a large number of followers. The origin of the Ovia cult is traced to a beautiful maiden named Ovia who lived in a town called Uhen. Many men wanted to marry her but she had told her parents when she was still very young that she would marry a king. When she reached marriageable age, the king of Oyo was in Benin and heard about her beauty. He visited her parents to ask for her hand in marriage. They agreed and started to get Ovia ready for the trip to Oyo. Since she was a child, Ovia 
had always worn a simple white cloth with red trimmings at the edge. When she was ready for the trip her father gave her the parting gifts of a water pot, a dog, and a parrot. He had already foreseen how her marriage would end. He encouraged her to come back home through the pot if her husband should maltreat her. When she arrived the place of the Oba of Oyo, the king placed her in a room very close to his and had an adjoining door between the two rooms so that he could visit her whenever he wanted.

The other wives were not pleased with the much love and attention the king bestowed on Ovia. One day, the most senior wife thought of a plan that would destroy the love the king had for his favourite wife, Ovia. She called all her cowives and asked them to accompany her to the farm to collect snails. Without the knowledge of Ovia, she asked the other wives to each come along with a bowl to place the snails in. At the farm, all the wives had their bowls filled with snails. Ovia had to tie hers in the white cloth she always wore. This became stained with the slime from the snails. When they got to the palace, and right before the king, the senior wife accused Ovia of having the abominable itee, an infection that causes consistent hemorrhage. She warned the king to be careful because he might be infected too. The king sent for Ovia and made her remove her outer clothes. The white cloth she always wore underneath indeed had a reddish stain. The co-wives laughed and taunted her mercilessly. She ran into her room, locked herself in, and wept bitterly. Later in the evening, the king pitied her and had a change of mind. He went to her door but she refused to open. By the time he forced himself in, he saw her already melting away in her tears. She fell into the pot her father had given her and turned into a river which flowed from her room, out of the palace, and to Uhen to meet her father. She told her father that "no woman should ever be allowed to know her secrets for it was women who caused her to leave her husband's house" (Bradbury, 1973:188).

This reason is usually cited to explain why women are not allowed to participate actively in any of the core areas of the Ovia rites. Other prohibitions are slammed against women. The rites and the constitution of the cult are handled by men. Most of the taboos of the cult are addressed to women. They must never touch the Ovia masquerade in any way. During the Ovia cult rites when the men would withdraw into the bush to prepare for the festival, women who walk along the bush path must continually shout, "behold an ignorant person" to forestall any chance meeting between them and the male Ovia adherents. The Ovia rites are shrouded in secrecy, which should never be revealed to women.

The Ovia cult also shares similarities with the Yoruba feminine cult of the Gelede, and the Ifa. Gelede is a Yoruba cult which primary purpose is to honour mothers who are believed to have the power to bless, or to destroy. The Ifa cult revolves around a myth that mentions Ifa as the favourite wife of Orunmila. Adherents claim that she (i.e. Ifa) wanted many aspects of the cult to be secret and to be in the hands of men only. The men carry out the important rites of the cult. The insistence of these deified female figures that only men should handle the sacred and secret aspects of their cults is a reflection of the general belief that women cannot keep secrets. Only men are initiated into the aforementioned female cults. Women are mainly onlookers.

There are some observations made from the Ovia cult worship, key of which are that when the festival is about to commence, the cult's members, all male, take a leave of absence, between one week to three months, from their families and move into the bush to prepare and organise the event. Secondly, no sexual relations is allowed during the festival. Four masquerades come out during the night to dance - the Oyo, Igbe, Edion, and the most revered masquerade, the Erinmwi. The dances are vigorous and the dancers are men. Four main dances are enacted: the first is in honour of the ancestors; the second in honour of the senior priest of the Ovia shrine; the third is in appreciation of the role of the senior priest assistants; and the fourth is for women, as mothers and wives. The other dances outside these four are for the good of the community. These dances are usually accompanied by songs rendered by the female onlookers. The songs are full of praises for the great exploits and services performed by men to the development of the community. The songs also express the women's dependence on their men, while calling both sexes to come together and work for the success of the festival.

\subsubsection{Ovia, Psychoanalysis, and the 'Other' Woman}

In reaction to the Hegelian theory of "the complete discourse" or "absolute knowledge", Jacques Lacan postulates the theory of the unconscious where he argues that the mind is both the conscious and the unconscious, and that the presence of the subconscious or the unconscious proves that knowledge cannot be absolute because the unconscious is unrecognisable knowledge, a "knowledge which can't tolerate one's knowing that one knows" (Unpublished Seminar Paper, February 19, 1974). To expand this view, Felman (1982: 47) equates unconsciousness with ignorance - not the normal lack of information, but a deliberate, and sometimes instinctive act to forget and obliterate from consciousness, "to not admit to knowledge."

Applying this strand of theory to the deity called Ovia, in order to cope with the oppression she experienced from the malicious behaviour of her co-wives, she pushed her oppression into her subconscious by her "desire to ignore", and her "resistance to knowledge" (Felman: 417) of her suffering and patriarchally inscribed inferiority. She replaced the ugly incidence and shame she experienced in her matrimonial home with two 'empowering' experiences. The first was the joy of punishing the offender - for her co-wives act of treachery against her, she turned into a water deity in a big river, named after her, and placed a curse that "no woman should ever be allowed to know her secrets". This is why women assume very insignificant roles in Ovia cult worship ceremonies; they are barred from being involved in the secrets of the cult. Secondly, the goddess, Ovia, pushed her humiliating experience in the hands of her co-wives into her unconscious realm by replacing it with an empowering one - the fawning adoration of the opposite sex. So, she took back the respect and dignity she could not get from her female folk from the opposite sex, the socially superior sex, the 
men. This way, her hurtful feelings, since then, are continually assuaged by the adoration accorded her yearly in her cult worship. This is why till today, the Ovia cult and its worship and ceremonies are handled by priests and male adherents.

Freud admits:

...psychoanalysis has taught us that the individual's emotional attitudes to other people... are established at an unexpectedly early age... The people to whom (the child) is in this way fixed are his parents. (Strachey, 1961: 242-44).

Freud explains this emotional response as "transference" (Standard, xi, 242-44), which Lacan defines as "the acting out of the reality of the unconscious" (Standard, xi, 150, 240). In effect, women having been socially conditioned to be inferior, grow up acknowledging the male as superior. In order to claim part of that superiority for themselves, they perpetuate acts of violence on their fellow "inferior" women through the social strata of class, ethnicity, and race. Ovia's co-wives in the King's palace were brought up on Simone de Beauvoir's the 'Other' conditioning, where they see other women as threats and competitors, and so make every move to 'eliminate' the undesirable elements. The only people women do not see as 'enemies' are their female family members, common examples being their mothers.

\section{Conclusion}

Many of the deities honoured today were once human beings who experienced all the passions and challenges that are part of human existence. Through supernatural means, they attain a higher realm and became benevolent benefactors to their spiritual subjects. However, being once human, they still carry within them various passions, some of which could be volatile in nature. More importantly, the way they departed the world would also determine how they would relate with the mortal beings they left behind. For Ovia, then, are departure from the world, through her transformation into water, was hinged in pain and feelings of revenge against her kind, which she exacted in full: the relegation of her fellow women into the lowest rung of the social ladder.

Notwithstanding the generally perceived goodness Ovia bestows on her adherents, the modus operandi of her cult is a strong confirmation of her bias against women. Her gendered stand only re-inscribes the common view that it is only a few women - queens, princesses, priestesses, and goddesses that enjoy patriarchal privileges, which unfortunately, do not transmit into the lives of the majority of women.

\section{References}

Amadiume, Ifi. Male Daughters, Female Husbands. London: Zed Books, 1987. Print

---. Reinventing Africa. Matriarchy, Religion and Culture. London: Zed Books, 1998. Print.

---. Daughters of the Goddess, Daughters of Imperialism. New York: Zed Books, 2000. Print.

Barrett, Michele. Women's Oppression Today. Verso: London and New York, 1990. Print.

Bay, Edna. Wives of the Leopard: Gender, Politics, and Culture in the Kingdom of Dahomey. Chalottesville and London: University of Virginia Press, 1998. Print.

Belsey, Catherine. 'Constructing the Subject: Deconstructing the Text'. Literary Criticism, R.C. Davis and R. Schleifer (Eds.) New York: Addison Wesley Longman, 1998. Print.

Ben-Amos, Paula. The Art of Benin. New York, Thames and Hudson, 1980. Print.

Benbow, Camilla \& Robert Benbow. 'Biological Correlates of High Mathematical Reasoning Ability'. Progress in Brain Research 61, pp.469-90, 1984. Print.

Birke, Lynda. Changing Minds: Towards Gender and Science. Philadelphia: The Falmer Press, pp. 184-202, 1986. Print.

Bradbury, Robert. The Benin Kingdom and the Edo-Speaking Peoples of South-Western Nigeria. London: International African Institute, 1957. Print.

---. Benin Studies. London: Oxford University Press, 1973. Print.

Broverman, Donald et al. 'Roles of Activation and Inhibition in Sex Differences in Cognitive Abilities'. Psychological Review, 75, 23. pp. 100-25, 1998. Print.

Chukukere, Gloria. Gender Voices and Choices: Redefining Woman in Contemporary African Fiction. Enugu: Fourth Dimension Publishing Company Limited, 1995. Print.

Davis, Robert \& Ronald Schleifer. Literary Criticism. New York: Addison Wesley Longman Inc., 1998. Print.

Egharevba, Jacob. Concise Lives of the Famous Iyases of Benin. Lagos: Temi-Asunwon Press, 1947. Print.

---. The City of Benin. Benin: Aguebor Printers, 1952. Print.

---. A Short History of Benin. Ibadan: Ibadan University Press, 1960. Print.

Ezeigbo, Akachi. 'The Enemy Within: Women against Women in Novels by Selected Nigerian Female Writers'. Ihafa - A Journal of African Studies, vol. 1, pp. 7-13, 1993. 
Felman, Shosana. 'Psychoanalysis and Education: Teaching Terminable and Interminable'. Yale French Studies, vol. 63, pp. 145-170, 1982. Print.

Freud, Sigmund. On Creativity and the Unconscious. New York: Harper and Brothers, 1958. Print.

--- .The Interpretation of Dreams. New York: Avon Books, 1965. Print.

---. A General Introduction to Psychoanalysis. New York: Boni and Liveright, 1920. Print.

Fuss, Diana. Essentially Speaking: Feminism, Nature and Difference. New York: Routledge, 1989. Print.

Gallup, Jane. Feminism and Psychoanalysis: The Daughter's Seduction. London: Macmillan, 1982. Print.

Harding, Sandra. The Science Question in Feminism. Ithaca, N.Y.: Cornell University Press, 1986. Print.

---. The Racial Economy of Science. Ed. Bloomington: Indiana University Press, 1993. Print.

Ikpe, Eno. "The Role of Women in National Development". Nigeria Peoples and Cultures. Ed. Osuntokun, Abiodun. and Ayodeji Olukoju. Ibadan: Davidson Press, 1997. 254-255. Print.

---. "Food Economy and Food Culture in the Benin Empire". Journal of African Philosophy and Studies, vol. 2, no. 3, 1999. 107-123. Print.

Lacan, Jacques. The Ethics of Psychoanalysis, 1959-60, trans., Dennis Porter, London: Tavistock/Routledge, 1992. Print.

Nevadomsky, Joseph. Religious Symbolism in the Benin Kingdom. Albuquerque: University of New Mexico Press, 1993. Print.

Nnaemeka, Obioma. "Feminism, Rebellious Women, and Cultural boundaries: Rereading Flora Nwapa and her Compatriots". Research in African Literatures, vol. 26, no. 1, 1995. 5-25. Print.

---. Sisterhood, Feminisms and Power: From Africa to the Diaspora. Ed. Trenton, N.Y.: Africa World Press. Inc., 1998. Print.

Nzegwu, Nkiru. Family Matters: Feminist Concepts in African Philosophy of Culture. Albany: State University of New York Press, 2006. Print.

Ogbomo, Onaiwu. Where Men and Women Mattered. New York: University of Rochester Press, 1997. Print.

Ogundipe-Leslie, Omolara. 'The Study of Women through Imaginative Literature'. AAWORD Occasional Paper Series, no. 2, pp. 77-83, 1985. Print.

---. "The Female Writer and her Commitment". Women in African Literature Today. Ed. Eldred Jones, et al. Trenton, N.Y.: African World Press, 1987. 5-13. Print.

Oluwole, Sophie. Womanhood in Yoruba Traditional Thought. Germany: Iwalewa-Haus, 1993. Print.

Oyewunmi, Oyeronke. The Invention of Women. Minneapolis: University of Minnesota, 1997. Print.

---. African Gender Studies: A Reader. Ed. New York: Palgrave Macmillan, 2005. Print.

---. African Women and Feminism: Reflecting on the Politics of Sisterhood. Ed. N.Y.: African World Press, 2004. Print.

Peavy, Daryl. Kings, Magic, \& Medicine. Raleigh-Durham: Lulu Publishing, 2009. Print.

Pradel, Lucie. African Beliefs in the New World. Trenton, NJ: Africa World Press, Inc., 2000. Print.

Ryder, Alan. Benin and the Europeans: 1485-1897. London: Longman Group Limited, 1977. Print.

Salami-Agunloye, Irene. Idia, the Warrior Queen of Benin. Jos: Saniez Publications, 2008. Print.

Strachey, James. et al. The Standard Edition of the Complete Psychological Works of Sigmund Freud. Trans. and Ed. London: Hogarth Press and the Institute of Psycho-Analysis, 1961. Print.

Wertheim, Margaret. Pythagoras' Trousers: God, Physics and the Gender Wars. New

York: Random House, 1995. Print. 